\title{
FILSAFAT CINTA MUHAMMAD IQBAL
}

\author{
Rohmat Suprapto \\ Universitas Muhammadiyah Semarang (UNIMUS) \\ e-mail:rohmat@unimus.ac.id
}

\begin{abstract}
In the academic world, Iqbal is known as a poet, philosopher, sufism, historian, and politician. The professions which he elaborated could reach the peak levels in their respective fields of life. In addition to his character, the concept he introduced and the reflection of his life were not only a synergy with Islamic law that derived from the Qur'an and As Sunnah, but also indeed both codices that leads his way of life. Due to these facts, he was dubbed as greatest Mujaddid in 20-th century.One of the concepts that makes him well recognized is the concept of love as expressed in a series of poems and was described as' ishq. 'Ishq is given from birth as God's grace by which will be cultivated and tested during the life to encounter all forms of humanity impairment leading to the perfection of life with the title 'the perfect Man'. Inside there is a blend of love and sense of intellect, love and reason, vision and power that are manifested in acts of prayer and work of scientists, and crystallized in the life of mysticism and scientism.
\end{abstract}

Abstrak:Dalam dunia akademik, Iqbal dikenal sebagai penyair, filosof, sufisme, sejarawan, dan politikus. Profesionalisme yang ia tekuni mencapai tingkat puncaknya di atas masing-masing bidang kehidupan ini, di samping karakternya, baik level konseptual maupun refleksi hidupnya, bukan hanya sinergi dengan syariat Islam yang bersumber kepada Al-Quran dan sunnah Rasululillah, melainkan memang kedua naskah kuno itulah yang menuntun jalan hidupnya.Pantas kalau ia digelari mujaddidterbesar di abad 20.Satu diantara konsep yang menjadikan ia memperoleh nama besar adalah konsepnya tentang cinta yang diungkap dalam rangkaian puisi dan ia sebutnya sebagai 'isyq. 'Isyq diperoleh sebagai bawaan lahir dari rahmat Tuhan yang dengannya dipupuk dan diuji dalam medan kehidupan sambil menepis segala bentuk pelemahkan kemanusian menuju ke-sempurna-an hidup dengan predikat 'the perfect Man'. Di dalamnya berpadu antara cinta dan akal intelek, love and reson, vision and power yang diwujudkan 
ROHMAT SAPUTRO:Filsafat Cinta Muhammad Iqbal

dalam tindak shalat dan kerja ilmuwan, dan mengkrital dalam kehidupan mistisime syar'i

Keywords: cinta, intelek, the Perfect Man, khaliffah Allāh, waḥdah al-wujūd.

\section{A. Pendahuluan}

Muhammad Iqbal yang secara luas dikenal sebagai penyair, praktisi hukum, filosof atau sekurang-kurangnya pemikir, Negarawan, juga seorang sufi lahir di Sialkot, Punyab yang sekarang termasuk wilayah Pakistan pada tanggal 9 November1877, ${ }^{1}$ tetapi ia sendiri mengaku lahir pada $1876 .^{2}$ Perbedaan catatan kelahiran ini begitu mudah dipahami bahwa pada saat kelahirannya belum ada yang memperhatikan secara khusus bahwa di kemudian hari akan menjadi pribadi besar, dan rupa-rupanya belum ada tradisi legal tentang catatan akte kelahiran di saat itu. Ia meninggal pada tanggal 20 April 1938. ${ }^{3}$

Bakat kepenyairannya dibuktikan melalui sebagian besar karya-karyanya yang ditulis dalam bentuk syair, seperti: Asrar-i Khudi (Rahasia Pribadi), Rumuz-i Bikhudi (peniadaan Diri), Payam-i Mashriq (Pesan Dari Timur), Bang-i Dara (Genta Lonceng), Zabur-i Ajam (Taman Rahasia baru), Javid Namah (Berpetualang Menuju keabadian), Pasche Bayad Aye Aqwam-i Syarq (Apa yang kau lakukan hai Rakyat Timur?), Musafir (Pengembara), Bal-i Jibril (Sayap Jibril), Zarb-i Kalim (Pukulan Musa), Armaghan-i Hijaz (Hadiah dari Hijaz). Sejumlah syair yang ia bacakan dalam helatan-helatan sastra cukup banyak $^{4}$, di samping dalam bentuk kumpulan cerama, artikel, pernyataan dan surat lebih dari 200 buah. ${ }^{5}$ Bakatnya sebagai pemikir politikus tidak kurang dari 29 artikel. ${ }^{6}$ Puisi-puisi Iqbal banyak mengilhami pejuang-pejuang kemanusiaan di bumi ini melalui terjemahan berbagai macam bahasa internasional. "Asrar-i Khudi" disalin ke dalam bahasa Inggris oleh R.A.Nicholson dengan judul "The Secrete of the Self"; "Payam-i Mashriq" diterjemahkan oleh Hadi Hussain dengan judul "A Massage from the East"; "Javid Namah" 
diterjemahkan ke dalam banyak bahasa, antara lain: "The Pilgrimage of the Etternity" oleh Mahmud Ahmad, Mohammad Sadikin menyalinnya ke dalam bahasa Indonesia dengan judul "Kitab Keabadian". Annemarie Schimmel menerjemahkannya ke dalam bahasa Jerman dengan judul: "Buch der Ewigheit". Terjemahannya ke dalam bahasa Turki berjudul "Gavidname", ke dalam bahasa Belanda berjudul "Einige Benerkungen Zu Mohammad Iqbal's Gavidname”, dan terjemahannya ke dalam Bahasa Perancis oleh Mayerovitch dan Mohammad Mokri dengan judul "Le Livre de L'eternite".7 Abdul Wahhab 'Azzam menerjemahkan "Payam-i Mashriq" ke dalam bahasa Arab-Mesir dengan judul 'Risālah al-Masyriq". Karya terakhir ini juga diterjemahkan ke dalam bahasa Indonesia Abdul hadi W.M. dengan judul "Pesan Dari Timur". Sementara itu, Annemarie Schimmel menerjemahkan Bal-i Jibril ke dalam bahasa Inggris dengan judul "Gabriel Wings". Tentu masih banyak lagi terjemahanterjemahan lainnya mengingat bahwa baik di Eropa, Asia, maupun Timur tengah banyak bermunculan yayasan atau kelompok studi yang mengkhususkan tentang gagasan-gagasan Iqbal.

Telah menjadi pengetahuan umum bahwa Iqbal-lah pemilik gagasan berdirinya Negara Pakistan. Untuk itu, di negri ini terdapat hari libur nasional untuk memperingati jasa Iqbal dengan nama "Iqbal Day", jatuh pada tanggal Sembilan November. ${ }^{8}$ Selain itu, ia terlalu banyak menempati posisi dan jabatan penting bagi lahirnya Negara Islam Pakistan, antara lain: anggota dewan legislatif di Punyab, Presiden Komite Kasmir, dan pemimpin konferensi Muslim India. Format politik yang ia gagas adalah integralisme antara moral dan politik ${ }^{9}$ dan antara kesatuan budaya dan wilayah. Maksudnya, orang-orang Hindu menempati Negara yang di sebut India dan orang-orang Islam menempati wilayah yang disebut Pakistan. Jika tidak demikian, maka perang saudara antara kaum Hinduisme dengan kaum muslimin tidak akan ada berhentinya. Demikian peringatan keras Iqbal untuk pemisahan Negara antara India dan Pakistan ini: ${ }^{10}$ 
ROHMAT SAPUTRO:Filsafat Cinta Muhammad Iqbal

Think of they country, 0 throughtless, trouble is brewing

In heavens there are designs for thy ruin

See that which is happening and that which is the happen,

What is there in the stories of olden time?

If you fail to understand this, you will be extraminated

O.of Hindustan!

Even you story will not be preserved in the annals of the world

Kapasitas Iqbal sebagai filosof, antara lain terindikasikan melalui karya magnum opus-nya yang berjudul "The Reconstruction of Religious Thought in Islam" menjadikan namanya begitu harum hingga sekarang. Itulah sebabnya ia juga digelari Mujaddid alfu sani. Sementara itu, predikatnya sebagai sufi terlihat antara lain konsepkonsepnya tentang maqamat (stations) dalam dunia kesufian dan pemikirannya tentang insan kamil sebagaimana dituangkan dalam karyanya yang berjudul "Asrar-i Khudi", suatu kualitas puncak kemanusiaan, yaitu "manusia tuhan"11 yang bertolak belakang dengan konsep Nietzsche tentang "The Will of Power"(uebermensch manusia kuat menggantikan Tuhan setelah Tuhan dibunuh), sebagaimana digambarkan dalam "The Madman" suatu hipotitikofilosofis yang hakikatnya antiteisme mutlak. Demikian kilahnya: "God is dead/God remains dead/and we have killed Him. ${ }^{12}$ Sementara itu konsep Khudi dari Iqbal secara utuh meneguhkan kemanusiaan dinamis yang berketuhanan, tentunya sinergi dengan petunjuk alQuran tentang khalīfah Allāh fi al-arḍ. Segera disampaikan di sini bahwa, sufisme yang dianut Iqbal ia sebut tasawuf islami yang berporos pada tauhid dilawankan dengan mistik asing dengan menunjuk paham wahdatul wujud. Dalam hal ini ia mengatakan, bahwa Wahdah al-Wujūd bukanlah sebagian dari ajaran al-Quran. Sebab al-Quran membedakan secara penuh antara Khāliq dengan makhlūq dan hamba dengan yang disembah. ${ }^{13}$ Tokoh sufi dan 
ROHMAT SAPUTRO:Filsafat Cinta Muhammad Iqbal

penyair besar dan dipersepsi luas sebagai wali, yaitu Lisān al-Ghālib Hāfiẓal-Sirāzī, oleh Iqbal dikatakan sebagai penganut paham waḥdat al-wujūd, ia kritik amat tajam dan para pengagumnya menjadi marah pada Iqbal. Demikian bait-bait kritiknya:

Hati-hatilah pada Hafiz, si peminum

Pada pialanya, racun kefanaan

Pada kepalanya yang bersorban

Dua piala tertambatkan

Fakih para pemabuk, tokoh kaum miskin

Domba yang mengajar lagu, kemanjaan, dan daya tarik yang buta

Ia, lebih cerdik ketimbang domba Yunani

Melodi serulingnya adalah penghambat pikiran

Jauhilah pialanya

Karena bagi cendekia dan pembuat kebaikan

Ia bagai candu yang menawan. ${ }^{14}$

Dalam dunia kesufian, Hafidz sangat disanjung sebagai tokoh besar. Akan tetapi, di mata Iqbal orang tersebut tdak ada artinya karena mengajarkan praktik zuhud yang memiskinkan umat dengan puncak kesufian fana, secara literal berarti hancur, hilangnya kesadaran diri larut dalam kesadaran bertuhan. Cegah Iqbal demikian: /kendalikan diri di hadapan-Nya/dan janganlah kau fana' dalam lautan cahaya-Nya. ${ }^{15}$ Hafiz, bagi Iqbal satu steriotipe dengan Plato. Jauh hari, Iqbal menganjurkan umat agar menjauhi model pemikiran dan gaya hidup Plato. Belakangan muncul Hafiz. Untuk itulah ia menganjurkan lagi "jauhilah pialanya". Mengapa? Orang, jika telah merasa mengalami pengalaman ruhani 'bersatu dengan Tuhan', selanjutnya merasa dirinya paling beruntung dan bahagia. Akibatnya, apapun yang berbau 'duniawi' tidak ada artinya. Jika pola keberagamaan dibangun di atas pondasi miskin dan fana, begitu mudah dapat dihipotesiskan 'akan melahirkan keberagamaan primitif, lemah, dan melankolis. Sementara di dunia luar Islam, sebutlah peradaban Barat amat rakus dengan kemajuan ilmu pengetahuan dan teknologi yang berwatak mengeksploitasi apa saja 
ROHMAT SAPUTRO:Filsafat Cinta Muhammad Iqbal

yang bisa dijarah, yang penting mendatangkan keuntungan material, meskipun harus membunuh apa saja yang ingin dibunuh hanya dengan alasan demi perkembangan sains dengan doktrin "The science for the science" antara lain dari Fihte dan Bolzano yang keduanya berakar dari Jacues Alain Miller dan Francois Regnault, pararel dengan "the art for the art"16, tetapi alasan yang sebenarnya adalah bisnis sebagai perwujudan homoeconomicus. Sangat kontras dengan apa yang diinginkan oleh Iqbal. Melalui seluruh pemikiran dan syair-syair elegis dan heroik mengajak umat untuk membangun karakter bersteriotipe Musa, Ibrahim, dan Muhammad Rasulullah. Mereka, dengan bukti sejarah yang tidak bisa diingkari telah berhasil mengangkat martabat manusia sesuai dengan kehendak Tuhan sebagai khalīfah Allāh fi al-arḍ.

Mencitra Iqbal haruslah ditambahkan bahwa, meskipun ia keturunan kaum Brahmin ${ }^{17}$ pola keberagamaannya bersifat murni dalam arti non-sinkretisme. Pengaruh Hinduisme dari leluhurnya nihil dalam keberagamaan Iqbal. Ia berkata:/Pikir dan ciptakan sastra murni/baiklah kembali pada Arabi/condongkan hatimu lagi kepada salma Arabi/. Maksud Salma Arabi adalah al-Quran. ${ }^{18}$ Pola keberagamaan seperti itulah yang dikehendaki oleh al-Quran: Sesunguhnya Kami menurunkan kepadamu Kitab (al-Quran) dengan (membawa) kebenaran.Maka sembahlah Allah dengan memurnikan ketaatan kepada-Nya (QS. al-Zumar [39]:2).

Jika Kitab Suci bagi kaum muslimin itu ditelaah lebih seksama, ternyata seruan untuk beragama secara murni terulang sebanyak 21 kali. ${ }^{19}$ (Abdul Baqi, [t.th.]:302-3). Dengan demikian, keberagamaan sinkretisme sebenarnya tidak memiliki tempat yang aman menurut pernyataan-pernyataan kalam Tuhan itu sendiri. Refleksi Iqbal dalam kesufiannya menolak paham sastra dan sufisme Iran yang berbau agama kuno dan Qaramithah karena berusaha membebaskan dari aturan syariat, demikian antara lain isi surat Iqbal 
ROHMAT SAPUTRO:Filsafat Cinta Muhammad Iqbal

kepada Hasan Nizami tertanggal 30 Desember 1915 (Azzam, 1985:57).

\section{B. Akar Sejarah 'Cinta'}

Umumnya, pola keberagamaan sufi yang bertumpu pada penghayatan 'cinta' diasosiasikan pada Rābi'ah al-'Adawiyah (713801H), sufi wanita dari Basrah di Irak, tetapi sebenarnya berakar pada Ma'rūf bin Faizan Abū Maḥūẓ al-Ibid bin Firus al-Karkhī. ${ }^{20}$ Baginya, menyembah Tuhan bukan mengharap surga, tidak pula karena takut kepada neraka ${ }^{21}$, demikian pula pendirian Rābi'ah al'Adawiyah. Belakangan, beberapa tokoh seperti al-Junaid, Muhammad Ali al-katani, Abu Abdillah an-Najabi, dan Ibnu Abdush Shamad berada di barisan sufi mahabbah atau cinta. ${ }^{22}$ Penghayatan cinta ilahi seperti itu, tentu tidak memperoleh dasar dari al-Quran maupun al-Sunnah. Kitab Suci ini menjelaskan dalam beratus-ratus ayat tentang neraka yang secara keseluruhan menggambarkan kesengsaraan orang yang menentang Tuhan, umpama dengan ungkapan 'ażābun 'alìm (siksa yang amat pedih), 'aẓābun syadīd (siksa yang amat pedih), syadīd al-'iqāb (kerasnya siksaan), bi's almașir (sejelek-jelek tempat kembali), layazūqūna fihā bardan walā syarabā (di neraka merasakan dingin dan tidak memperoleh minuman), illā hamīman wa ghassāqā (dalam neraka terdapat air mendidih bercampur nanah, QS. al-Nabā' [78]:25). Nah, apakah orang yang tidak takut neraka dengan ungkapan yang sangat mengerikan itu tidak dapat dikatakan sombong?

Dalam hadis Nabi disebutkan bahwa, ibadah sekuat apapun tidak bisa dibanggakan sebagai tiket untuk masuk surga. Tiket surga hanya satu, rahmat Allah termasuk pribadi Nabi sendiri. Demikian sabda beliau:

$$
\text { لايدخل احدا منكم عمله الجنة ولا يجيره من النار ولا انا إلا برمة }
$$


ROHMAT SAPUTRO:Filsafat Cinta Muhammad Iqbal

Tidak dimasukkan salah seorang diantara kamu karena amal ke surga dan tidak juga diselamatkan dari neraka, begitu juga aku, kecuali karena rahmat (HR. Muslim).

Hanya perlu diingat, bahwa yang berpeluang memperoleh rahmat Allah tentunya yang taat kepada-Nya. Sabda beliau ini dapat dipahami bahwa beliau juga mengharapkan surga. Dalam kesempatan lain terkait dengan peristiwa azan, beliau bersabda demikian:

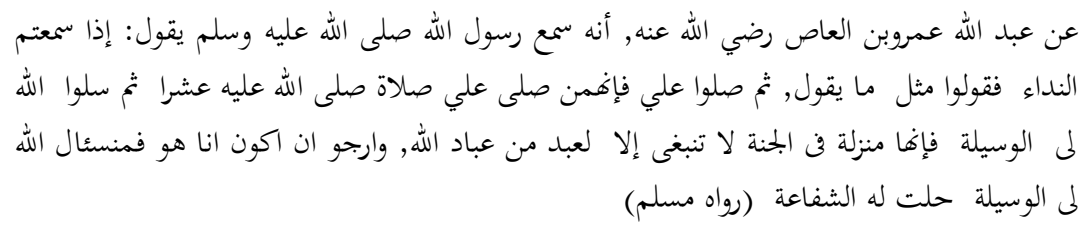

Dari 'Abd Allāh, 'Amr bin 'Aș ra, bahwa ia mendengar dari Rasulullah saw bersabda: apabila kamu mendengar undangan (azan), maka jawablah seperti ia mengatakannya, kemudian bershalawatlah untukku. Sesungguhnya, barang siapa bershalawat untukku satu kali, Allah akan bershalawat kepadanya 10 kali, lalu berdoalah kepada Allah untukku wasilah. Sesungguhnya, wasilah itu adalah suatu kedudukan di surga yang tidak pantas kecuali bagi hamba diantara hamba-hamba Allah. Aku berharap hamba itu adalah aku. Barang siapa yang memohon kepada Allah untukku wasilah, halal baginya syafaat (HR. Muslim).

Rasululah sebagai panutan seluruh umat Islam berharap ia kelak masuk surga dengan kedudukan wasilah (manzilatun fi aljannah), apatah artinya sufi penghayat cinta tidak takut neraka dan tidak berharap surga? Maka dengan penuh kesadaran, penulis harus menyatakan bahwa mereka itu kurang benar jika diukur dari syariat dan harapan pribadi Rasulullah sendiri. Kekeliruan konseptual penghayatan cinta ilahiyah seperti mereka praktikkan dalam pola keberagamaan itu perlu diluruskan kembali sebagaimana diajukan oleh Iqbal tentang konsep cinta ('isyq) sebagai hasil kristalisasinya meneladani Rasulullah. 


\section{Hakikat 'Isyq (Cinta)}

Mengihtisarkan gagasan Iqbal tentang 'isyq (selanjutnya ditulis cinta, untuk lebih meningkatkan level komunikasi kepada pembaca)ke dalam sebuah unit idea bukan lah merupakan pekerjaan mudah karena ide tentang cinta terserak di berbagai karyanya baik yang bersifat puisi maupun prosa, di samping selalu terkait dengan aspek gagasan lain. Dalam mengekplorasi gagasan 'cinta' versi Iqbal tentu ditempuh dengan cara mengaitkan aspek lain tersebut sejauh relefan dengan tujuan mempertajam pengertian hakiki dari idea 'cinta' itu sendiri.

\section{Cinta Sebagai Asal Kehidupan}

Iqbal menyatakan bahwa, cinta asal kehidupan dan haram baginya kematian, cinta menyingkirkan banjir datang melandai, sebab cinta adalah air pasang mengalun, tundukkan topan dan badai. ${ }^{23}$ Kutipan di atas mengandung pesan bahwa sekali manusia hidup sumbernya adalah cinta. Jika dihubungkan dengan konsep penciptaan alam semesta, dasar Allah mencaipta adalah cinta. Tertib ayat kesatu, kedua, dan ketiga dalam surat al-Fatihah terlihat jelas bahwa Allah sebagai Rabb al-'̄́lamīn (pencipta, pemelihara, pendidik, pengasuh, pengajar, dan pengatur alam semesta ${ }^{24}$ di atas pondasi maupun diliputi al-Raḥmān al-Rahīm (Yang Maha Pengasih lagi Maha Penyayang). Dalam hadis lebih eksplisit, sebagai bayān taqrīrī atau bayān ta'kidīi, ${ }^{25}$ akan Raḥmān Raḥìm sebagai dasar penciptaan. Demikian hadis yang dimaksud: Rasulullah saw bersabda: Ketika Allah menentukan penciptaan, Ia tulis di dalam kitab-Nya. Kitab itu ada di sisi-Nya di atas 'Arsy. Sesungguhnya Kasih sayang-Ku mengalahkan kemurkaan-Ku (HR. al-Bukhari dari Abi Hurairah). Dalam kesempatan lain, Iqbal bersenandung:

Tuhan mengajarkan Al-Quran kepada insan

dari tangan kami Allah melimpahkan Rahman

dan Rahimnya. ${ }^{26}$ 
ROHMAT SAPUTRO:Filsafat Cinta Muhammad Iqbal

Dengan demikian, pernyataan Iqbal di samping konsisten dengan pola pikir quraniknya, juga senafas dengan spirit al-Quran maupun al-Sunnah yang menyatakan bahwa cinta adalah dasar kehidupan.

\section{Cinta Sebagai Penggerak Perubahan Menuju Ke- sempurnaan}

Bagi Iqbal, cinta bukanlah satu diantara maqamat (station) sebagaimana konsepsi para sufi. Cinta bukan sesuatu perolehan atas dasar perjuangan yang berat (riyādah), melainkan merupakan instrumen untuk menuju kesempurnaan karena sumber kehidupan tanpa ujung tak kenal lelah dan gagal, begitulah dalam sajaknya yang berjudul Parlemen Setan', /Apakah cinta?/pengembaraan tanpa ujung/menerjang segala batas/menamatkan tujuan akhir/cinta tak kenal khatam, tak kenal akhir. . ./ia selalu ke depan dan tak kenal gagal $^{27}$ adalah cinta dan terus mengalir mengarungi kehidupan tetap dengan cinta. Demikian Iqbal menulis:

Oleh kemilau cinta marak menyala tanah lempung ini

Cinta anggur hampir matang, cinta piala bagi sang budiman

Cinta hamba beribadah, cinta panglima pasukan

Cinta ibnu sabil tiada terkira tempatnya singgah

Cinta jari pemetik lagu tali kehidupan

Cinta gemilang hayat, cinta api kehidupan. ${ }^{28}$

Penggal syair di atas harus dipahami bahwa cinta bukan merupakan tipologi keberagamaan melankolis sebagaimana 'cinta Platonis', sekedar hanya merasa cinta, dan yang dicintai mungkin sekali tidak merasakannya, cinta al-Masīh yang konon mengajarkan cinta "jika ditampar pipi kirimu berikan pipi kananmu tentu mengandung maksud jika penampar menghendaki bisa menampar pipi yang satunya. Kaum kristiani boleh apologis bukan harfiah itu yang dimaksud. Tetapi harap disadari, bagaimanapun ketika doktrin 
itu dikomunikasikan secara universal, tentu tidak bisa mengelak dengan makna yang harfiah itu. Cinta model Kristiani tentu akan membuat pipi bengap yang proyeksi lebih luas akan menimbulkan kesengsaraan universal. Ajaran ini tentu paradoks dengan tampilan empiris para pemeluk Kristen. Cinta model ini tentu bertolak belakang dengan ajaran Al-Quran. Kitab suci ini mengajarkan qișaș (QS. al-Baqarah [2]:178, 179, 194; al-Mā'idah [5]:45) terhadap segala bentuk kedhaliman untuk menegakkan keadilan dan ketentraman manusia itu sendiri, berbeda dari spirit HAM, yang ditafsirkan dan dilaksanakan secara salah, melindungi penjahat dan memasalalukan korban tetap dalam penderitaannya.

Cinta ideal Iqbal di samping berlaku lemah lembut kepada apa dan siapapun, juga terkadang harus tampak tegas laksana panglima pasukan yang memberikan komando "serang!, ledakkan!, Bunuh!, tahan, penjarakan" atau sebangsanya manakala keadaan harus menghendaki demikian. Tipe cinta seperti itulah yang diperagakan oleh Muhammad Rasulullah dan Rasul-rasul lainnya: Musa, Dawud, Sulaiman, Thalut, Ibrahim, dan Nuh. Rasulullah mengajarkan dan berakhlaq dengan cinta, tetapi juga memimpin perang berkali-kali demi membela kejayaan Islam dari musuh-musuh jahilnya. ${ }^{29}$ Atas dasar cinta sebagai sumber kehidupan dan penggerak menuju ke arah kesempurnaan, selanjutnya cinta memasuki ke bilik-bilik relung kehidupan yang lebih minor, namun tetap memiliki efek terhadap keseluruhan hidup, itulah uniknya gagasan Iqba, antara lain:

\section{a. Cinta Menjelmakan Prestasi Puncak Kemanusiaan}

Berkat kegigihan cinta sebagai pendorong menuju ke arah kesempurnaan, Iqbal membayangkan demikian fantastik pretasi yang diperoleh. Katanya:

Cinta adalah nafas Jibril

cinta adalah hati al-Mușțafā

cinta adalah utusan ilahi

TEOLOGIA, VOLUME 25, NOMOR 1, JANUARI-JUNI 2014 
ROHMAT SAPUTRO:Filsafat Cinta Muhammad Iqbal

cinta adalah gemilang hayat

cinta adalah api kehidupan. ${ }^{30}$

Ia menambahkan:

cinta adalah Plato yang menyembunyikan sakitnya pikiran

cinta adalah Mahmud yang merebut Sommath intelek. ${ }^{31}$

Sommath adalah kuil Hindu tempat pemujaan kepada pada para dewa di India yang menurut keyakinan umatnya tidak akan dapat dikalahkan oleh manusia karena saking kokohnya bangunan dan kuatnya penjagaan untuknya. Kenyataannya, Sultan Mahmud al-Gaznawi mampu mengalahkan pemuja dewa dan kuil tersebut. ${ }^{32}$ Jika diukur dari ajaran tentang al-asmā' al-ḥusnā dalam Islam, yang berhak sombong itu hanya Allah dalam asma-Nya al-Mutakabbir (QS.al-Hasyr [59]:23) karena Dia-lah yang mencipta dan memiliki seluruh makhluk. Harap segera dipahami bahwa alMutakabbir Allah inherent dengan asma-asma yang lain yang berjumlah 99 atau lebih. Satu diantaranya adalah al-'Alimm. Itulah sebabnya, dalam suatu kesempatan, Iqbal menjelaskan bahwa cinta itu tidak mandiri, jika dipadu dengan akal yang dalam konsep lebih makro adalah perpaduan antara mistisisme dan saintisme, atau antara love and reason dalam bahasa lain antara vision and power dengan simbol tindak shalat dan kerja ilmuwan ${ }^{33}$ akan mampu menjilmakan kualitas pribadi the Pervect Man. ${ }^{34}$

\section{b. Cinta Nihil dari Rasa Masgul}

Karakter cinta versi Iqbal menjauhkan diri dari rasa masgul, jengkel, gundahgulana dan galau. Katanya,

Bebas kami dari kesal dan sebal hari ini dan esok

kami berjanji mencintai Yang Tunggal

kamilah fitrah tersembunyi dalam kalbu Tuhan. ${ }^{35}$ 
Praksis pesan ini dapat dinyatakan bahwa meskipun berhadapan dengan suatu keadaan harus membunuh musuh Allah, rasa cinta harus tetap berada dalam kesadarannya. Ia membunuh harus tetap atas nama Allah. Demikian anjuran Nabi ketika menyembelih binatang: “. . . Barang siapa yang belum menyembelih, hendaklah menhyembelih dengan membaca basmalah" (HR. Muttafaqun 'alaih dari Jundab). Pisau yang digunakan untuk menyembelih harus setajam mungkin sehingga tidak menimbulkan sakit sama sekali terhadap binatang yang disembelih. ${ }^{36}$

\section{c. Cinta Menepikan rasa Takut}

Dengan semangat cinta mampu menghalangi apapun dalam rangka meraih tujuan setinggi-tingginya hingga derajat kemanusiaan yang dapat dicapai manusia, yaitu 'manusia tuhan'. Demikian Iqbal menulis:

Cinta tidak takut kepada pedang dan belati

Cinta tidak berasal dari air dan bumi

Cinta menjadikan damai dan perang di dunia

Sumber hidup ialah kemlau pedan cinta

Tebing yang paling keras gemetar oleh tinjauan cinta

Cinta ilahi akhirnya mewujudkan Tuhan

Maksud mewujudkan Tuhan bukan dirinya mengaku sebagai Tuhan laksana Fir'aun (QS. al-Nāzi'at [79]:24), melainkanistilah kaum sufi, makrifatullah karena Iqbal mengacu kepada apa yang diperagakan dalam tradisi hidup oleh Nabi Nuh dan Nabi Ayub yang ia identifikasi sebagai insān kāmil dalam kualitas pribadi, selanjutnya menjadi penerang dunia semesta. ${ }^{37}$ 
ROHMAT SAPUTRO:Filsafat Cinta Muhammad Iqbal

\section{d. Cinta adalah Ketaatan Sejati}

Iqbal berujar:

Antara sifat demi sifat, 'isyq adalah taat sejati

Orang suci dari Bistam amat asli patuhnya

Ia selalu puasa dari buah mentimun

Wahai sang 'asyik, tetaplah kau dalam kebaktian

Kepada yang dikasihi

Agar dapat kau lempar jerat dan menangkap Tuhan. ${ }^{38}$

Jika dianalisis secara lebih seksama, antara cinta dan taat merupakan sekeping mata uang yang tampak dari dua sisi tetapi hakikatnya adalah satu. Kesimpulan ini dipahami dari penggal syair sebagai berikut:

oleh ketaatan setiap orang yang tak bernilai menjadi tinggi

siapa yang menguasai matahari dan bintang

jadikan ia ditawan oleh undang-undang. ${ }^{39}$

Tentu, yang ia maksudkan dengan undang-undang adalah kitab suci al-Quran dan al-Sunnah. Praksis dari cinta semacam ini mewujud dalam semua keadaan yang muncul baik dari dalam diri maupun dunia eksternal. Diilustrasikan bahwa jika ada kemungkaran, ia tidak benci terhadap si-nakir dan efek kemungkarannya. Meskipun begitu, pelaku cinta tetap mengubah suasana kemungkaran menjadi sesuatu yang maslahat, damai, tenteram, dan sejahtera meskipun harus dengan kekerasan karena itulah jalan satu-satunya setelah melalui berbagai macam analisis aqli maupun naqli. Jika dengan cara non kekerasan sudah cukup berpeluang untuk merubahnya, maka cara itulah yang bijak yang harus diterapkan. Dengan demikian, tampilan praktisnya berbuat dengan tegas, tetapi landasan berbuat adalah cinta. 


\section{e. Cinta Pelerai Semua Konflik}

Dikisahkan bahwa Bu Ali, Laqab dari Syeikh Syarafuddin serorang sufi dari Panipath memiliki seorang murid yang melaksanakan ajaran kesederhanaan sufi. Suatu saat sang murid terlibat berdebat dengan gubernur setempat. Dari berdebat meningkat menjadi konflik karena sang gubernur melakukan penganiayaan kepadanya. Setelah Bu Ali mengetahui konflik ini, ia berkirim surat kepadanya. Serta-merta gubernur-yanglengkap memiliki segelar-papan pasukan tunduk diam dan melakukan rekonsiliasi dengan muridnya tersebut, meskipun ia hanyalah sufi dari rakyat biasa. ${ }^{40}$ Bahkan Iqbal membayang bahwa cinta dapat mengubah negri yang penuh bencana menjadi taman surgawi. Demikian ia bersyair:

Bila pribadi diperkuat dengan cinta

menjadikan negri bencana ini menjadi surga firdaus.41 (bahrum,1976:129).

Berkaca dari sejarah bangsa-bangsa di dunia bahwa siapapun memerintah negri dilandasi dilandasi dengan cinta maka akan memakmurkan negri itu. Sulaiman, Dawud, dan Rasulullah adalah contoh-contoh konkrit dalam membangun negri yang oleh Al-Quran dikategorikan baldatun thayyibatun wa Rabbun Ghafur (QS. As-Saba'/34:15).

\section{f. Karakter Cinta Membentuk Kesabaran}

Ketika Iqbal menelaah syair-syair berbahasa Persia dari para kampiun sastrawan dan sufi, rata-rata bernada cengeng. Iqbal tidak simpati karena itu ia pandang akan melemahkan Islam wal muslimin, maka dengan penuh semangat ia bersenandung:

Wajahnya yang juita bercacat oleh lukisan pensilmu

'Isyq malu pada dirinya oleh keluh dan tangismu 
ROHMAT SAPUTRO:Filsafat Cinta Muhammad Iqbal

Dan lemah tiada berdaya oleh kendurnya semangatmu

Pialanya penuh dengan air matamu percuma

Rumahnya diliputi oleh keluh tiada berguna..22 (Bahrum, 1976: 141).

Dengan tepat Iqbal menggambarkan ketabahan laksana rumput yang diinjak-injak, ia bisa tumbuh sewaktu-waktu tanpa ada keluhan pada rumput itu.

Terapan cinta dalam peradaban dunia kontemporer yang secara umum mencabut akar kemanusiaan sebagaimana yang terjadi di berbagai belahan dunia, seperti perang saudara di Timur Tengah, Anarkhisme di negri tercinta yang bernama Indonesia, gaya Amerika sok menjadi polisi dunia tidak harus diratapi dengan tangis dan aneka keluhan, melainkan dihadapi dengan penuh sabar dan tabah sambil mencari peluang bagaimana misi Islam rahmmatan li al-'âlamīn dapat direalisasikan. Demikian ajakan Iqbal bangun dari kekerdilan pribadi para sufi:

Ah jika adalah serimis sajak dalam bajumu

Gosoklah dia dengan batu ujian kehidupan

Cita murni menunjuk jalan ke amal perbuatan

Penaka kilat mendahului Guntur

Pikir dan ciptakanlah sastra murni

Baliklah kembali kepada Arab

Condongkan hatimu lagi kepada Salma Arabi

Agar pagi kemilau Hijaz

Menguntum dari malam Kurdistan

Inti himbauan penggalan syair ini adalah 'jangan mengeluh dengan nasib yang kurang menguntungkan, kemudian bangunlah dengan penuh semangat dengan landasan salma Arabi, yaitu basmillah pada setiap memulai 
aktifitas dan berpedoman kepada al-Quran. ${ }^{43}$ Prosedur pembangunan peradaban Islam dengan berpedoman pada salma Arabi telah terbutkti ampuh antara lain menunjuk pada sampel kejayaan imperium Parsi, Iran, dan India. Demikian lanjutan syair di atas:

kau telah kumpulkan kembang dari tamansari Farsi

dan melihat musim kembang India dan Iran. ${ }^{44}$

Karena begitu hebatnya cinta, ibarat hanya mengerdipkan mata maka setumpuk mawar dalam taman sari tiba-tiba muncul. Lebih dari itu, masjid Cordoba di Spanyol terbentuk karena cinta, laksana hamba Allah dari umat Nabi Sulaiman yang dalam waktu lebih cepat dari kerdipan mata mampu memindahkan istana Balkis ke hadapan beliau (QS. alNaml [27]:40). ${ }^{45}$

\section{g. Cinta Sebagai dentitas Iman}

Iqbal menyatakan bahwa cinta adalah iman itu sendiri. Dalam arti jika ada orang mengaku beriman tetapi tidak ada cinta dalam dirinya ia katakannya sebagai kafir. Ia menghendaki di dalam dirinya iman sepenuhnya dan cinta sepenuhnya. Ia bersenandung:

hiasi dirimu dengan rona Ilahi

hormatilah dan jayakan cinta

tabiat seorang muslim diliputi oleh cinta

muslim yang tak bercinta menjadi kafir. 46

Untuk memudahkan pemahaman dua hal sama-sama memenuhi hati laksana dua lampu pijar dalam satu ruangan yang masing-masing sinar tebarannya memenuhi ruanangan itu. kesenyawaan antara iman dan cinta menyatu dalam kebergantungannya kepada Allah dan bersemayam dalam 'Tiada Tuhan selain Allah.'47 
ROHMAT SAPUTRO:Filsafat Cinta Muhammad Iqbal

\section{Penutup}

Konsep Iqbal tentang cinta merupakan antitesisme dari doktrin maqamat sufisme. Baginya, cinta diperoleh sebagai bawaan dengan argument bahwa seluruh makhluk tercipta atas dasar cinta, bukan perolehan dengan tindak menempuh hidup 'memiskinkan' diri seraya menutup potensi akal sebagaimana doktrin dan praktik hidup kaum darwisi melalui rute zuhud material. Bagi sufisme, cinta diperoleh ketika kesadaran diri fana' lebur dalam cahaya ilahi. Tetapi,ending-nya amat paradoks, justru menampilkan tipologi hidup dalam keberagamaan melankholis.

Perlawanannya terhadapcinta sufisme sedemikian gigih itu dilakukan karena melemahkan hakikat martabat yang sebenarnya telah diberikan oleh Allah begitu terhormat sebagai wakil-Nya di bumi ini. Tidak pelak lagi doktrin cinta Iqbal ditujukan untuk mengembalikan martabat manusia menuju tipologi 'the Pervect Man', laksana Ibrahim, Musa, Sulaiman, Dawud, dan Muhammad. Mereka ini pantas menyandang gelar khalifah Allāh fi al-arḍ.Di dalam pribadi mereka berpadu antara cinta dan akal intelek, antara tindak shalat dan kerja ilmuwan, dan antara mistisisme dan saintisme.[]

\section{Catatan Akhir}

${ }^{1}$ M. Iqbal, Rekonstruksi Pemikiran Iqbal: Studi tentang Kontribusi Gagasan Iqbal dalam Pembaharuan Islam, Padang: Kalam Mulia, 1994, h. 44 .

${ }^{2}$ Annemarie Schimmel, Gabriel's Wing: Study into the Religious Ideas of Sir Muhammad Iqbal,Karachi: Iqbal Academy, 1989, h. 35.

${ }^{3}$ Hafeez Malik, Iqbal: Poet-Philosopher of Pakistan, New YorkLondon: Columbia University, 1971, h. 35.

4Danusiri, Epistemologi Dalam Tasawwuf Muhammadi Iqbal, Yogyakarta: Pustaka Pelajar, 1996, h. 37.

IIhsan Ali Fauzi dan Nurul Agustina, Sisi Manusiawi Iqbal, Bandung: Mizan, 1992, 164-168.

${ }^{6}$ Danusiri, Epistemologi, h. 37-40. 
${ }^{7}$ Hafeez Malik, Iqbal, h. 419.

${ }^{8}$ en.wikipeda.org/wiki/iqbal.Day.

9Syed Abdul Vaid, Iqbal, His Art and Thought, London: Luzac \& Co., 1976, h. 271.

${ }^{10}$ Ali Audah, dkk, Membangun Pikiran Kembali Pikiran Agama Dalam Islam, Jakarta: Tintamas, 1982, h. 37.

11Komentar Bahrum Rangkuti terhadap karya terjemahannya untuk Mohammad Iqbal, Rahasia-Rahasia Pribadi, Jakarta: Bulan Bintang, 1953, h. 156.

12J. J. Thomas Altizer,, Toward a New Christianity: Reading in the Death of God Theology, New York: Harcourt-Brace\&Word Inc., 1967, h. 83.

${ }^{13}$ Abdullah Wahhab 'Azzam, Filsafat dan Puisi Iqbal, terj. Ahmad Rafi Usman, Bandung: Penerbit Pustaka, 1985, h. 59.

${ }^{14}$ Abdullah Wahhab 'Azzam, Filsafat, h. 56-57.

15Ibid., h. 56.

16M.M. Syarif, Iqbal Tentang Tuhan dan Keindahan, Bandung: Mizan, 1984, h. 114.

${ }^{17}$ Abdullah Wahhab 'Azzam, Filsafat, h. 13.

18Mohammad Iqbal, Rahasia-Rahasia Pribadi, terjemah dan komentar oleh Bahrum Rangkuti, Jakarta: Bulan Bintang, 1953, h. 16.

${ }^{19} \mathrm{Aḥmad}$ Fuad Abd al-Baqi', al-Mu'jam al-Mufahras li Alfāz alQur'ān al-Karìm, Indonesia: Maktabah Dahlan, tth., 302-303.

${ }^{20}$ Harun Nasution, Falsafat dan Mistisisme Dalam Islam, Jakarta:

Bulan Bintang, 1973, h. 71.

21http://www.pejalanruhani.com/2013/03.

${ }^{22}$ Muhammad Abu Bakar Kalabadzi, M, Ajaran-Ajaran Sufi, terj.

Nasir Yusuf, Bandung: Pustaka, 1985, h. 150.

23Mohammad Iqbal, Rahasia, h. 29, 182.

${ }^{24}$ Hamka, Tafsir al-Azhar, Juzu' I, Jakarta: Pustaka Panjimas, 1982, h. 102.

${ }^{25}$ Abdul Madjid Khon, Ulumul Hadis. Jakarta: Amzah, 2012, h. 1819.

26Mohammad Iqbal, Rahasia, h. 176.

${ }^{27}$ Djohan Effendi dan Abdul Hadi W.M, Iqbal: Pemikir Sosial Islam dan Sajak-sajaknya, Jakarta: Pantja Sakti, 1986, h. 113.

28Mohammad Iqbal, Rahasia, h. 182.

${ }^{29} \mathrm{Abd}$ al-Baqi', al-Mu'jam, h. 605-661.

30Mohammad Iqbal, Rahasia, h. 182. 
31Ibid., h. 171.

32Ibid.

33Mohammad Iqbal, The Reconstruction of Religious Thought in Islam, Lahore: Kitab Bhavan, 1981, h. 92.

${ }^{34} \mathrm{M}$. Saeed Sheikh, Studies in Iqbal's Thought and Art, Lahore:Bazm-i Iqbal, 1972, h. 246.

35Mohammad Iqbal, Rahasia, h. 176.

36Serangkaian eksperimen Schultz dan Hazim, animals scientist, dari Hanover University di German dengan memasang EEG (Encephalo Electro Graphy)dan ECG untuk mendeteksi syaraf perasa sakit yang berpusat pada otak kecil dan detak jantung terhadap binatang yang disembelih dengan pisau tajam dibandingkan dengan meyembelih binatang dengan didahului metode stuning, model Barat. Diperoleh hasil bahwa alat tersebut tetap menunjukkan angka 0 sebelum disembelih hingga enam menit kemudian, di mana binatang itu benarbenar mati. Hal ini menunjukkan bahwa binatang itu tidak merasakan sakit. Sementara dengan metode stuning, yaitu dipukul dengan benda keras (captive bolt pistol) pada kepala binatang sembelihan tersebut meskipun kelihatan pingsan, tetapi pandom alat itu menunjukkan peningkatan untuk beberapa saat yang berarti menunjukkan rasa sakit pada binatang. Disebutkan juga membunuh dengan menembak jantungnya dari jarak dekat masih mengalami sakit antara 10-20 menit. Membunuh dengan cara menyuntik (anastasia) yang dieksekusi merasakan sakit minimal delapan menit (Nanung Dono Danar, Telaah Singkat Syaria't Islam: Ibadah Penyembelihan Hewan Qurban, Yogyakarta: Fak Peternakan UGM, tth., h. 1-51). Kesimpulannya, konsep cinta versi Iqbal nihil dari sebal, galau, marah terbukti dengan ekspierimen Schultz dan Hazim tersebut. Benar pula sabda Rasulullah tentang cara menyembelih binatang, yaitu ihsan kepadanya.

37Mohammad Iqbal, Rahasia, h. 125.

${ }^{38}$ Mohammad Iqbal, Rahasia, h. 26.

${ }^{39}$ Abdullah Wahhab 'Azzam, Filsafat, h. 78.

40Mohammad Iqbal, Rahasia, h. 129.

${ }^{41}$ Ibid.

42Ibid., h. 141.

43Ibid., h. 142.

${ }^{44}$ Ibid.

45Ibid., h. 182.

${ }^{46}$ Abdullah Wahhab 'Azzam, Filsafat, h. 83. 
ROHMAT SAPUTRO:Filsafat Cinta Muhammad Iqbal

${ }^{47}$ Abdullah Wahhab ‘Azzam, Filsafat, h. 83.

TEOLOGIA, VOLUME 25, NOMOR 1, JANUARI-JUNI 2014 


\section{DAFTAR PUSTAKA}

'Abd al-Bāqī, Aḥmad Fu'ad, al-Mu'jam al-Mufahras li Alfāz al-Qur'ān al- Karim, Indonesia: Maktabah Dahlan, tth.

'Azzam, Abdullah Wahhab, Filsafat dan Puisi Iqbal, terj. Ahmad Rafi Usman, Bandung: Penerbit Pustaka, 1985.

Abdul Baqi', al-Lu'lu u wa al-Marjān, Surabaya: Bina Ilmu, 2007.

Altizer, J. J. Thomas, Toward a New Christianity: Reading in the Death of God Theology, New York: Harcourt-Brace\&Word Inc., 1967.

Audah, Ali, dkk, Membangun Pikiran Kembali Pikiran Agama Dalam Islam, Jakarta: Tintamas, 1982.

Danar, Nanung Dono, Telaah Singkat Syaria't Islam: Ibadah Penyembelihan Hewan Qurban, Yogyakarta: Fak Peternakan UGM, tth.

Danusiri, Epistemologi Dalam Tasawwuf Muhammadi Iqbal, Yogyakarta: Pustaka Pelajar, 1996.

Efendi, Djohan, dan Abdul Hadi.W.M, Iqbal: Pemikir Sosial Islam dan Sajak-sajaknya, Jakarta: Pantja Sakti, 1986.

Fauzi, Ihsan Ali, dan Nurul Agustina, Sisi Manusiawi Iqbal, Bandung: Mizan, 1992.

Hamka, Tafsir al-Azhar, Juzu' I, Jakarta: Pustaka Panjimas, 2005.

Imam Bukhari, , Shahih al-Bukhari, Semarang: Thoha Putra, tth.

Iqbal, M., Rekonstruksi Pemikiran Iqbal: Studi tentang Kontribusi Gagasan Iqbal dalam Pembaharuan Islam, Padang: Kalam Mulia, 1994.

Iqbal, Mohammad, Metafisika Persia, terj. Joebar Ayoeb, Bandung: Mizan, 1990.

Iqbal, Mohammad, Pesan dari Timur, terj. Abdul Hadi W.M, Bandung: Pustaka, 1985. 
PETUNJUK PENULISAN ARTIKEL

Iqbal, Mohammad, Rahasia-Rahasia Pribadi, terj. Bahrum Rangkuti, Jakarta: Bulan Bintang, 1953.

Iqbal, Mohammad, The Reconstruction of Religious Thought in Islam, Lahore: Kitab Bhavan, 1981.

Kalabadzi, Abu bakar M, Ajaran-Ajaran Sufi, terj. Nasir Yusuf, Bandung: Pustaka, 1985.

Khon, Abdul Madjid, Ulumul Hadis. Jakarta:Amzah, 2012.

Malik, Hafeez, Iqbal: Poet-Philosopher of Pakistan, New York-London: Columbia University, 1971.

Naisaburī, Abū al-Ḥusain Muḥsin bin al-Ḥajjaj ibn Muslim al-Qusyairī, al-Jāmi' al-Ṣahīḥ, Beirūt: Dār al-Fikr, tth.

Nasution, Harun, Falsafat dan Mistisisme Dalam Islam, Jakarta: Bulan Bintang, 1973.

Schimmel, Annemarie, Gabriel's Wing: Study into the Religious Ideas of Sir Muhammad Iqbal. Karachi: Iqbal Academy, 1989.

Sheikh, M.Saeed, Studies in Iqbal's Thought and Art, Lahore:Bazm-i Iqbal, 1972.

Syarif, M.M, Iqbal Tentang Tuhan dan Keindahan, Bandung: Mizan, 1984

Vahid, Syed Abdul, Iqbal, His Art and Thought, London: Luzac \& Co., 1976. 